\title{
Sociodemographic and
} Maternal Risk Factors Associated with Psychomotor Retardation in Infants under Two Years Old in Tabasco

Factores de riesgo sociodemográficos y maternos asociados al retraso psicomotor en infantes menores de dos años en Tabasco

Fatores de risco sociodemográficos e maternos associados ao atraso psicomotor em crianças menores de dois anos em Tabasco

\author{
Estefany Ramírez Pérez ${ }^{1,2}$ \\ Alexis Neme García1,3 \\ Julio César de la Cruz González ${ }^{1,4}$ \\ Edgar García Rojas, PhD ${ }^{1 *}$
}

Received: September 17, 2019 • Accepted: May 13, 2020

Doi: https://doi.org/10.12804/revistas.urosario.edu.co/revsalud/a.9792

To cite this article: Ramírez Pérez E, Neme García A, Cruz González JC de la, García Rojas E. Sociodemographic and Maternal Risk

Factors Associated with Psychomotor Retardation in Infants under Two Years Old in Tabasco. Rev Cienc Salud. 2020;18(3):1-11. https:// doi.org/10.12804/revistas.urosario.edu.co/revsalud/a.9792

\section{Abstract}

Introduction: Adequate psychomotor development during the first years of life significantly impacts the growth of each infant, so the timely detection of risk factors that affect this development is of vital importance. The objective was to determine sociodemographic and maternal factors associated with the presentation of psychomotor retardation in infants under two years old who attended the Centro de Rehabilitación y Educación Especial in Villahermosa (Tabasco, Mexico) in 2017. Materials and methods: An observational, retrospective study of cases and controls in infants under two years old. Data collection

1 Universidad del Valle de México, Villahermosa Campus (México).

Corresponding author: edgarojas.89@gmail.com ORCID: https://orcid.org/0000-0003-0580-4174

2 ORCID: https://orcid.org/0000-0001-6162-3891

3 ORCID: https://orcid.org/0000-0003-2603-8093

4 ORCID: https://orcid.org/0000-0003-0580-4174 
was performed using a questionnaire consisting of 45 questions, which included variables such as psychomotor retardation, prenatal, perinatal, and postnatal risk factors, that used Pearson's chi-square test and Fisher's exact test, with a significant correlation of $p<.05$ being accepted. Results: A low social class showed a significant relationship with psychomotor retardation ( $p=.000$ ), while the presence of infections at a very young age in the newborn, a family history of psychomotor retardation, and a history of disease during pregnancy showed a value of $p<.05$. Conclusion: A low socioeconomic status, pregnancyassociated diseases such as malnutrition, high blood pressure, and traumatic accidents, as well as infectious diseases at birth were the main factors that conditioned psychomotor retardation.

Keywords: Psychomotor retardation; vertical transmission of infectious diseases; medical history taking; socioeconomic factors.

\section{Resumen}

Introducción: el adecuado desarrollo psicomotor en los primeros años de vida influye significativamente en el crecimiento de cada sujeto, por lo que la detección oportuna de factores de riesgo que lo afecten es de vital importancia. El objetivo fue determinar factores sociodemográficos y maternos asociados a la presentación del retraso psicomotor en infantes menores de dos años que acudieron al Centro de Rehabilitación y Educación Especial en Villahermosa (Tabasco, México) en el 2017. Materiales y métodos: estudio observacional, retrospectivo de casos y controles en infantes menores de dos años. Los datos se recolectaron mediante un cuestionario de 45 ítems, que incluyó variables como retraso psicomotor, factores de riesgo prenatales, perinatales y posnatales. Se emplearon las pruebas chi cuadrado de Pearson y la prueba exacta de Fisher. Se aceptó una correlación significativa de $\mathrm{p}<0.05$. Resultados: el estrato social bajo mostró una relación significativa con el retraso psicomotor $(p=0.000)$, así como la presencia de infecciones a una edad muy temprana en el recién nacido, el historial de antecedente familiar y el antecedente de enfermedad en el embarazo $(\mathrm{p}<0.05)$. Conclusión: un estatus socioeconómico bajo, enfermedades asociadas al embarazo como malnutrición, hipertensión arterial y accidentes traumáticos, además de las enfermedades infecciosas al nacer, fueron los principales factores que condicionaron el retraso psicomotor.

Palabras clave: retraso psicomotor; transmisión vertical de enfermedades infecciosas; toma de historial médico; factores socioeconómicos.

\section{Resumo}

Introdução: o adequado desenvolvimento psicomotor nos primeiros anos de vida impacta significativamente no crescimento de cada sujeito, pelo que a detecção oportuna de fatores de risco que o afetem é de vital importância. O objetivo foi determinar fatores sociodemográficos e maternos associados à apresentação do atraso psicomotor em crianças menores de dois anos que acorrem ao Centro de Reabilitação e Educação Especial em Villahermosa (Tabasco, México) em 2017. Materiais e métodos: estudo observacional, retrospectivo de casos e controles em crianças menores de dois anos. A recolecção de dados se realizou mediante um questionário de 45 itens o qual incluiu variáveis como atraso psicomotor, fatores de risco pré-natais, perinatais, e pós-natais, empregando as provas qui-quadrado de Pearson, prova exata de Fisher. Se aceitou uma correlação significativa de $\mathrm{p}<.05$. Resultados: o estrato social baixo mostrou relação significativa com o atraso psicomotor ( $\mathrm{p}=.000$ ); também a presença de infeções a uma idade muito precoce no recém-nascido, o historial de antecedente familiar e antecedente de doença na gravidez (p<.05). Conclusão: o status socioeconômico baixo, doenças associadas à gravidez como subnutrição, hipertensão arterial e acidentes traumáticos, para além das doenças infeciosas ao nascer, foram os principais fatores que condicionaram o atraso psicomotor.

Palavras-chave: atraso psicomotor; transmissão vertical de doenças infeciosas; tomada de historial médico; fatores socioeconômicos. 


\section{Introduction}

Dychomotor development is defined as the set of skills that an infant acquires during the first two years of life, comprising the motor, cognitive, socio-affective, language, and sensory areas (1-4). In addition to the above, a delay in motor development can be caused by different risk factors, such as birth weight, gestational age, intrauterine growth restriction, mother's education and sociodemographic level. Play-based interventions and those that promote shared reading are more effective and feasible in developing countries (5-9).

Infants in rural areas of developing countries are twice as likely to present low birthweight when compared with infants from urban areas, and 65\% are likely to suffer from growth retardation (10). During the peri-gestational period, a series of factors that can influence or condition the normal growth and development of the fetus come together (11-13).

During the postnatal stage, the most frequent factors are respiratory distress syndrome, meningitis, periventricular hemorrhage, trauma, seizures, hyperbilirubinemia, hypoxia, and macro or microcephaly. The presence of the latter is in the range of approximately $12 \%$ in neuropediatrics; $50 \%$ of these are attributed to delayed motor maturation $(14,15)$. Therefore, the objective of this study was to determine the sociodemographic and maternal risk factors associated with psychomotor retardation in infants that attend the sirs rehabilitation ward (sala infantil de tratamiento integral) - a comprehensive treatment ward for children at the Centro de Rehabilitación y Educación Especial in Villahermosa, Tabasco in 2017.

\section{Materials and methods}

retrospective, observational case-control study was conducted on infants under two - years old that attended the sirs ward at the Centro de Rehabilitación y Educación Especial in Villahermosa, Tabasco in 2017.

The study population included those patients who visited the service during the months of January-June 2017, selected using non-probability convenience sampling, showing a 1:1 case and control correlation.

The case selection criteria included patients under two years of age who attended the rehabilitation ward with a diagnosis of psychomotor retardation. Exclusion: infants under two years old with psychomotor retardation secondary to other pathologies such as Down syndrome and infantile cerebral palsy, among others.

With regard to the control selection criteria, children under two years old were included when they were admitted to the unit without a diagnosis of psychomotor retardation and without clinical symptoms suggestive of it. 
Patients with an inconclusive diagnosis suggestive of psychomotor retardation were excluded.

Data collection was performed using a 45-item questionnaire, which included variables such as the medical history diagnosis of psychomotor retardation and perinatal risk factors, such as the presence of trauma prior to the consultation or cases of previous infections reported by the mother or guardian, etc. were classified dichotomously. The data suggested by the socioeconomic evaluation carried out by the institution's social work department was used for the socioeconomic class assessment.

The data was processed and analyzed using the spss statistical program, version 23. Pearson's chi-square test and Fisher's exact test were used for the correlation of the variables, together with the odds ratio (OR), a 95\% confidence interval (cI), and a significant association of variables with a $\mathrm{p}<.05$ value was accepted.

This investigation was conducted following the Declaration of Helsinki guidelines and the Ley General de Salud (General Health Law) in its last reform, which was published DoF 06-01-2016, under the Fifth Title “Investigación para la Salud,” a single chapter; articles 96 and 100, which mentions health research as an act that contributes to the development of knowledge of biological and psychological processes in humans $(16,17)$. The children's guardians agreed to participate after signing an informed consent. This project was presented to and approved by the teaching field of the Centro de Rehabilitación y Educación Especial of the State of Tabasco and the Research and Ethics Committee of the Universidad del Valle de México, Villahermosa Campus.

\section{Results}

eventy infants with psychomotor retardation and 70 clinically healthy pediatric patients

without the condition under study were assessed; 43 of the cases were male and 27 were female.

The mean age of the infants was $3.26 \pm 1.24$ months for the confirmed cases and $3.02 \pm$ 1.09 months for the controls.

The majority of the children who attend the entity's rehabilitation center are from the municipality where the center is located, followed by Nacajuca in the state of Tabasco, as well as from the state of Chiapas (Figure 1). 


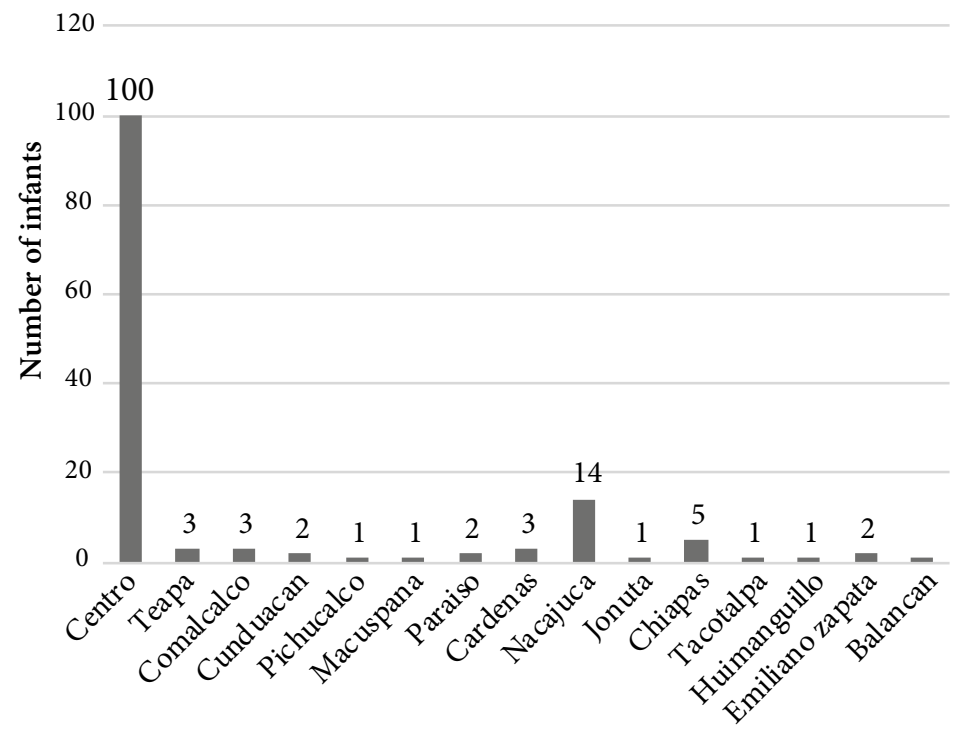

Figure 1. Location of the infants that were treated at the clinic

Regarding the sociodemographic factors, only a low socioeconomic status showed a significant association with the presentation ( $\mathrm{p}=.000 ; 95 \% \mathrm{CI}=0.349-0.80$ ). The other variables such as the presence of piped water, location and drainage showed no relationship ( $p$ >.05) (Table 1).

Table 1. Relationship between sociodemographic factors and infants with psychomotor retardation

\begin{tabular}{|c|c|c|c|c|c|c|c|}
\hline Variable & $\begin{array}{c}\text { Psychomotor } \\
\text { retardation }\end{array}$ & $\begin{array}{c}\text { No psychomotor } \\
\text { retardation }\end{array}$ & OR & $95 \%$ сI & gl & Value & $\mathbf{p}$ \\
\hline \multicolumn{8}{|l|}{ Location } \\
\hline Urban & 34 & 42 & 0.63 & $0.3222-1$ & 1 & 1.84 & $0.175^{*}$ \\
\hline Rural & 36 & 28 & & & & & \\
\hline \multicolumn{8}{|l|}{ Piped water } \\
\hline Yes & 68 & 69 & 0.493 & $0.044-5$ & 1 & 0.341 & $0.559 *$ \\
\hline No & 2 & 1 & & & & & \\
\hline \multicolumn{8}{|l|}{ Drainage } \\
\hline Yes & 58 & 63 & 0.537 & 0.198-1. & 1 & 1.52 & $0.217^{*}$ \\
\hline No & 12 & 7 & & & & & \\
\hline \multicolumn{8}{|c|}{ Socioeconomic status } \\
\hline Mean & 24 & 53 & 0.16 & $0.349-0.80$ & 1 & 24.27 & $0.000 *$ \\
\hline Low & 46 & 17 & & & & & \\
\hline \multicolumn{8}{|l|}{ Wall material } \\
\hline Brick & 13 & 6 & & & 3 & 5.679 & $0.128 *$ \\
\hline Block & 53 & 60 & & & & & \\
\hline Laminate & 4 & 2 & & & & & \\
\hline Wood & & 2 & & & & & \\
\hline
\end{tabular}

*Pearson's chi-square test. 
In relation to maternal history, a positive family history of psychomotor retardation showed 10-fold increased risk of presentation of the event ( $\mathrm{p}=.000 ; 95 \% \mathrm{cI}=3.82-35.61$ ). Mothers who presented with a disease during pregnancy had 3-fold increased risk of presentation compared to those who were clinically healthy $(\mathrm{p}=.002 ; 95 \% \mathrm{cI}=1.603-8.84)$, and a history of a traumatic accident showed 5 -fold increased probability of presentation $(\mathrm{p}=.015$; 95\% cI = 1.32-18.76) (Table 2).

Table 2. Relationship between maternal factors and the presentation of psychomotor retardation

\begin{tabular}{|c|c|c|c|c|c|c|c|}
\hline & $\begin{array}{l}\text { Psychomotor } \\
\text { retardation }\end{array}$ & $\begin{array}{l}\text { No psychomotor } \\
\text { retardation }\end{array}$ & OR & $95 \%$ сI & gl & Value & $\mathbf{p}$ \\
\hline \multicolumn{8}{|c|}{ Family history } \\
\hline Positive & 29 & 4 & 11.67 & $3.82-35.61$ & 1 & 24.781 & $0.000^{*}$ \\
\hline Negative & 41 & 66 & & & & & \\
\hline \multicolumn{8}{|c|}{ Disease during pregnancy } \\
\hline Positive & 25 & 9 & 3.76 & $1.603-8.84$ & 1 & 9.94 & $0.002^{*}$ \\
\hline Negative & 45 & 61 & & & & & \\
\hline \multicolumn{8}{|c|}{ Medications intake } \\
\hline Positive & 5 & 4 & 1.29 & $0.326-4$ & 1 & & $0.500+$ \\
\hline Negative & 65 & 66 & & & & & \\
\hline \multicolumn{8}{|c|}{ Illegal substance } \\
\hline Positive & 0 & 3 & 2.045 & $1.72-2$ & 1 & 3.066 & $0.080^{*}$ \\
\hline Negative & 70 & 67 & & & & & \\
\hline \multicolumn{8}{|c|}{ Traumatic accident } \\
\hline Positive & 13 & 3 & 5.09 & $1.32-18.76$ & 1 & & $0.015+$ \\
\hline Negative & 57 & 67 & & & & & \\
\hline \multicolumn{8}{|c|}{ Type of delivery } \\
\hline Vaginal & 38 & 37 & 1.05 & $0.545-2$ & 1 & 0.029 & $0.865^{*}$ \\
\hline Abdominal & 32 & 33 & & & & & \\
\hline \multicolumn{8}{|l|}{ Gender } \\
\hline Male & 43 & 29 & 1.26 & $0.645-2$ & 1 & 0.471 & 0.49 \\
\hline Female & 27 & 31 & & & & & \\
\hline
\end{tabular}

*Pearson's chi-square test; + Fisher's exact test.

Regarding perinatal factors, only cases that were positive for infectious diseases prior to the consultation were more predominant in infants with psychomotor retardation $(p=.000$; $95 \%$ cI $=9.60-555.718)$ (Table 3). 
Table 3. The relationship between perinatal factors and psychomotor retardation

\begin{tabular}{|c|c|c|c|c|c|c|c|}
\hline & $\begin{array}{c}\text { Psychomotor } \\
\text { retardation }\end{array}$ & $\begin{array}{c}\text { No psychomotor } \\
\text { retardation }\end{array}$ & or & $95 \% \mathrm{cI}$ & gl & Value & $\mathbf{p}$ \\
\hline \multicolumn{8}{|c|}{ Traumatic history } \\
\hline Positive & 10 & 4 & 2.75 & $0.819-9$ & & & $0.157+$ \\
\hline Negative & 60 & 66 & & & & & \\
\hline \multicolumn{8}{|c|}{ Infectious disease history } \\
\hline Positive & 36 & 1 & 73.059 & $9.60-555.718$ & 1 & 45.001 & $0.000^{*}$ \\
\hline Negative & 34 & 69 & & & & & \\
\hline \multicolumn{8}{|c|}{ Pregnancies } \\
\hline First & 33 & 41 & & & 5 & 9.51 & $0.090^{*}$ \\
\hline Second & 19 & 21 & & & & & \\
\hline Third & 12 & 5 & & & & & \\
\hline Fourth & 5 & 1 & & & & & \\
\hline Fifth & 0 & 2 & & & & & \\
\hline Sixth & 1 & 0 & & & & & \\
\hline
\end{tabular}

*Pearson's chi-square test; + Fisher's exact test.

\section{Discussion}

The psychomotor retardation approach includes a series of variables that need to be analyzed. Since motor alteration has a direct impact on the central nervous system, attention should not only focus on the musculoskeletal system but also on all of the aspects affected by the presentation.

Therefore, continuous follow-up in the postnatal stage is of vital importance. At the Hospital Sor María Ludovica in Argentina, in a follow-up of 140 apparently healthy infants from six to nine months of age, $22.5 \%$ were at risk of developmental delay, $13 \%$ of language delay, $3 \%$ of delayed motor skills, and $5 \%$ of coordination disorders (18).

According to the aforementioned, there are several sociodemographic factors that directly affect psychomotor development that are attributable to the presentation of the condition during the first months of life such as a lower social class. Within this section, among the factors associated with the presence of psychomotor retardation, detection is more readily seen in the infant population in Cuenca, Ecuador, which has twice the risk of presentation of the condition, frequently associated with microcephaly. The risk for the presence of this abnormality is 17 times higher and twice as prevalent in family groups with a non-nuclear structure (19). 
It is evident that the presentation of the condition affects various tracts and systems, as well as life processes, combined with a 3.91 increase in the degree of malnutrition in infants who are suffering from the disease. Given the above, there is no doubt that various factors can influence the condition and improvement of the healthcare. However, the condition has not shown an affinity for a particular gender, according to the results obtained.

Maternal factors are related to the frequency of presentation and its impacts on the appropriate evolution. It is indisputable that sociodemographic and economic factors directly influence the rehabilitation of the patient. Leiva and Valdés emphasize that household income, as well as the educational level of the head of household had a significant impact on the presentation of psychomotor retardation in four and five-year-old school children from Talca, Chile. However, in a population from Robert Manuel Zulueta Calvo in Havana, an unsuitable socioeconomic level shows a five-fold increased risk of association with the disease $(20,21)$.

Furthermore, late preterm infants are more predisposed to presenting hypoglycemia, jaundice, oculomotor alterations, as well as communication, fine motor, and social-individual skills disorders. With regard to the Ages \& Stages Questionnaires scale used for the detection of neurodevelopmental disorders, the female group had a greater weight compared to the male group at the Severo Ochoa University Hospital in Leganés, Madrid (22).

According to the socioeconomic class applied to the study population by the Departamento de Trabajo Social in Tabasco, a significant relationship was found with a low socioeconomic status, while sex showed no affinity. As for the demographic factors, there is overcrowding and basic sanitation, but they showed no significant relationship. Compared to the results, the variables of location, piped water, and wall material showed no relationship either.

When carrying out the economic impact analysis, it is outstanding that it continues to focus on the presentation of the alterations, since the lower strata are an important focal point regarding the incidence of the condition. Therefore, urban areas are susceptible to various pathology presentations, for which a direct attribute cannot be presented.

In this regard, maternal factors that are directly related to the presentation of the case such as previous malnutrition during pregnancy, previous hypertension, and amniotic fluid problems can also be considered triggers of generalized developmental disorders such as Autism Spectrum Disorder and Asperger's Syndrome (23). Compared to the results obtained, the presence of illness during pregnancy is cited as a factor associated with psychomotor retardation with three times the risk of presentation in the infant and a traumatic accident has five times the risk of presentation. In addition to this, similarities in the presentation of results were found with maternal factors such as a history of contagious infectious diseases and a low IQ, as well as diseases during pregnancy, with regard to the presentations of infants with psychomotor development disorders (24-26). 
Finally, all the aforementioned emphasizes the importance of investigating the causes that can be related with the presentation of the pathology, since the prognosis is related to the magnitude of the origin and the rehabilitation therapy to be carried out for each infant being of the utmost importance.

Various factors are related to the presence of psychomotor retardation in the newborn during his first months of life, such as a low social class. The presence of infections such as hyperbilirubinemia, toxoplasmosis, and heart disease at a very early age in the newborn can lead to delayed psychomotor development compared to clinically healthy children. Therefore, within the recommendations, adequate prenatal within the first level of care remains to be a fundamental

pillar of health care, as a frequent amount of cases in a family history shows a high relationship with the presentation of cases, as well as suffering from diseases during pregnancy or a history of trauma, which affects the incidence of the disease along with a late or torpid rehabilitation. In addition to this, nutrition and the importance of an adequate diet during pregnancy deserves a timely reference.

During the postnatal stage, intervention in the area of psychology regarding both familial processes and social coping strategies in which the affected patient will be involved are also important. Hearing and language, together with rehabilitation for the early correction of speech, mobility and strength, as well as family support during the process, must also be addressed.

\section{Authors Contribution}

The contributions by Estefany Ramírez Pérez, Alexis Neme García, Julio César de la Cruz González focused on the conception of the study idea, drafting of the method, preparation of the instruments and data collection, and literature review. Edgar García Rojas contributed to the organization, analysis, tabulation and interpretation of results, drafting and discussion.

\section{Conflict of Interests}

None declared. 


\section{References}

1. Cigarroa I, Sarqui C, Zapata Lamana R. Efectos del sedentarismo y obesidad en el desarrollo psicomotor en niños y niñas: una revisión de la actualidad latinoamericana. Univ Salud. 2016;18(1):158-9. https://doi.org/10.22267/rus.161801.27

2. Noguera Machacón LM, Herazo Beltrán Y, Vidarte Claros JA. Correlación entre perfil psicomotor y rendimiento lógico-matemático en niños de 4 a 8 años. Rev Cienc Salud. 2013;11(2):185-94. https://dx.doi.org/10.12804/revsalud14.03.2016.04

3. Rosario Montejoa O, Molina Rueda F, Munoz Lasa S. Effectiveness of equine therapy in children with psychomotor impairment. Neurología. 2015;30(7):425-32. https://doi. org/10.1016/j.nrleng.2013.12.017

4. Vericat A, Orden AB. El desarrollo psicomotor y sus alteraciones: entre lo normal y lo patológico. Cien Saude Colet. 2013;18(10):2-3. http://doi.org/10.1590/\$1413-81232013001000022

5. López Pisón J, Monge Galindo L. Evaluación y manejo del niño con retraso psicomotor: trastornos generalizados del desarrollo. Rev Pediatr Aten Primaria. 2011;13(Suppl 20):131-44.

6. Hartkopf J, Schleger F, Keune J, Wiechers C, Pauluschke Froehlich J, Weiss M, et al. Impact of intrauterine growth restriction on cognitive and motor development at 2 years of age. Front Physiol. 2018;9(1278):1-7. https://doi.org/10.3389/fphys.2018.01278

7. Schonhaut L, Rojas P, Kaempffer AM. Factores de riesgo asociados a déficit del desarrollo psicomotor en preescolares de nivel socioeconómico bajo: comuna urbano rural, Región Metropolitana, 2003. Rev Chil Pediatr. 2005;76(6):589-98. http://dx.doi.org/10.4067/S037041062005000600006

8. Hopp CA, Baron IS. Birth at 22 gestational weeks: case report of cognitive resilience. Clin Neuropsychol. 2017;31(2):471-86. https://doi.org/10.1080/13854046.2016.1224802

9. Fernández Mayoralas D, Fernández Jaén A, Fernández Perrone A, Calleja Pérez B. Detección y manejo del retraso psicomotor en la infancia. Pediatr Integral. 2015;19(8):532-9.

10. Polańska K, Jurewicz J, Hanke W. Smoking and alcohol drinking during pregnancy as the risk factors for poor child neurodevelopment: a review of epidemiological studies. Int J Occup Med Environ Health. 2015;28(3):419-43. https://doi.org/10.13075/ijomeh.1896.00424

11. Coles CD, Kable JA, Keen CL, Jones KL, Wertelecki W, Granovska IV, Pashtepa AO, Chambers CD; CIFASD. dose and timing of prenatal alcohol exposure and maternal nutritional supplements: developmental effects on 6-month-old infants. Matern Child Health J. 2015;19(12):2605-14. https://doi.org/10.1007/s10995-015-1779-x

12. Parada Rico D, López Guerrero N, Martínez Laverde M. Bajo peso al nacer y su implicación en el desarrollo psicomotor. Rev Cíenc Cuidad. 2015;12(2):87-99. https://doi. org/10.22463/17949831.511

13. Fabre Grenet M, García Méric P, Bernard Niel V, Guagliardo V, Cortaredona S, Aymeric Ponsonnet M. Effects of deformational plagiocephaly during the first 12 months on the psychomotordevelopment of prematurely born infants. Arch Pediatr. 2017;24(9):80210. https://doi.org/10.1016/j.arcped.2017.01.022 
14. Moreno Villagómez J, Prieto Corona B, Muñoz Bellizzia JA, García Méndez A, Hernández Echeagaray E. Evaluación neuropsicológica de niños mexicanos con craneosinostosis simple con el inventario de Desarrollo Battelle. Rev Mex Neuroci. 2014;15(6):327-34. https://doi.org/10.31190/rmn.2018.19.4

15. Ortiz Venegas A, Robayo Gutiérrez V, Alejo de Paula L. Revisión sistemática de las intervenciones para la estimulación en niños con retraso motor de 0 a 12 meses de edad. Mov Cient. 2014;8(1):118-30. https://doi.org/10.33881/2011-7191.mct.\%25x

16. Barrios Osuna I, Anido Escobar V, Morera Pérez M. Declaración de Helsinki: cambios y exégesis. Rev Cub Salud Pública. 2016;42(1):132-42.

17. Secretaría de Salud. Ley General de Salud [internet]. [Cited 2019 Feb 23. Available from: http://www.salud.gob.mx/unidades/cdi/legis/lgs/LEY_GENERAL_DE_SALUD.pdf

18. Romero MF, Copparoni JP, Fasano MV, Sala M, Mansilla M, Vericat A, et al. Assessment of sensorimotor intelligence and psychomotor development in clinically healthy infants assisted in the public health sector. Arch Argent Pediatr. 2019;117(4):224-9.

19. Huiracocha L, Robalino G, Huiracocha M, García J L, Pazán C, Angulo A. Retrasos del desarrollo psicomotriz en niños y niñas urbanos de 0 a 5 años: estudio de caso en la zona urbana de Cuenca, Ecuador. Maskana. 2012;3(1):13-28.

20. Leiva M, Valdés M. Modelo estadístico para predecir el puntaje de desarrollo psicomotor de niños de 4 a 5 años de edad en función del nivel socioeconómico. Arch Pediatr Urug. 2016;87(1):22-7.

21. López Gómez S. Prevalencia de los factores de riesgo perinatales en los trastornos generalizados del desarrollo. Univ Psychol. 2012;11(3):875-83.

22. Gutiérrez Cruz N, Torres Mohedas J, Carrasco Marina ML, Olabarrieta Arnal I, Martín Del Valle F, García García ML. Desarrollo psicomotor en prematuros tardíos a los dos años de edad: comparación con recién nacidos a término mediante dos herramientas diferentes. Rev Neurol. 2019;68:503-9. https://doi.org/10.33588/rn.6812.2018360

23. Moreno Mora R, Barahona Anangonó M. Maltrato infantil y factores sociodemográficosambientales asociados a niños con retraso del desarrollo psicomotor (Habana Vieja, 2010-2013). Rev Cub Neurol Neurocir. 2016;6(1):17.

24. Wheater M, Rennie JM. Perinatal infection is an important risk factor for cerebral palsy in very-lowbirthweight Infants. Dev Med Child Neurol. 2000;42(6):364-7.

25. Xing L, Wang G, Chen R, Ren J, Qian J, Huang Y. Is chorioamnionitis associated with neurodevelopmental outcomes in preterm infants? A systematic review and meta-analysis following PRISMA. Medicine. 2019;98:50(e18229). https://doi.org/10.1097/ MD.0000000000018229

26. Hedderich DM, Bäml JG, Menegaux A, Avram M, Daamen M, Zimmer C, et al. An analysis of MRI derived cortical complexity in premature-born adults: regional patterns, risk factors, and potential significance. NeuroImage. 2020;208:116438. https://doi.org/10.1016/j. neuroimage.2019.116438 